\title{
MUSCULOSKELETAL DISORDERS RELATED TO THE PROFESSIONAL WORK OF ACADEMIC TEACHERS AND THE QUALITY OF THEIR WORK
}

doi: 10.2478/cqpi-2019-0007

Date of submission of the article to the Editor: 26/04/2019

Date of acceptance of the article by the Editor: 24/05/2019

Marta Niciejewska1 - orcid id: 0000-0003-1936-9919

Serhii Kasian² - orcid id: 0000-0002-7103-4457

${ }^{1}$ Częstochowa University of Technology, Faculty of Management, Department of Production Engineering and Safety, Poland

2 Faculty of Economics, OlesHonchar Dnipro National University, Department of Economic Theory and Marketing, Ukraine

Abstract: The organization of space and working conditions is very important in terms of its effectiveness. Each professional work determines activities that support occupational safety and health at the workplace. Lack of proper working conditions but also the time of exposure to dangerous, burdensome or harmful factors has an impact on the effectiveness of the work performed. Lack of balance between work and leisure in turn results in a decrease in work efficiency. The scientific and didactic work of academic teachers is related to the occurrence of diversified occupational hazards with particular emphasis on those that are the cause of musculoskeletal disorders. In this elaboration, the research, analysis and evaluation of the work effectiveness of academic teachers have been carried out. A questionnaire and a direct interview have been used as a research method. In addition, the pain intensity in individual parts of the body has been assessed in the last 12 months depending on the age of research and teaching staff using the NMQ questionnaire (Nordic Musculoskeletal Questionnaire). For the purposes of the study, the survey was supplemented with the VAS (Visual Analogue Scale) scale to assess the severity of pain. The purpose of the paper is to evaluate the frequency and severity of musculoskeletal pain in academic teachers with regard to the effectiveness of their work

Keywords: academic teacher, musculoskeletal disorders, Nordic Musculoskeletal Questionnaire, Visual Analogue Scale, work safety.

\section{INTODUCTION}

Every professional work carries with it risks that have an impact on human health and life. Depending on the type and nature of work, hazardous (accidental) and harmful hazards are distinguished (Klimecka-Tatar and Niciejewska, 2016a;Niciejewska and Klimecka-Tatar, 2018; Szabó and Németh, 2019). Threats of a bothersome or harmful nature are first and foremost: physical (noise, lighting, microclimate, etc.), biological, 
chemical and psychophysical (Kogi et al., 2019;). However, even the huge advances in technology have not solved the problems of safety and health in the work environment. Technological development has only moved the area of the biggest threats, among others, from physical, chemical and dust hazards to biological and psychophysical ones,. For this reason, today's protection of work, more than ever before, must place pay attention on people's limited psychophysical capabilities in the work environment. (Koradecka 2008). According to data from studies carried out by the European Agency for Safety and Health at Work, the most frequently reported complaints associated with psychophysical work are musculoskeletal disorders. These complaints most often affect people employed in agriculture and civil engineering (EU-OSHA 2017).The group of professions exposed to high musculoskeletal discomforts, mainly due to their work position, also includes dentists, which in addition, work under conditions of high psychophysical load (Niciejewska and Klimecka-Tatar, 2016b).Musculoskeletal disorders are the problem that often occur in the working population. According to data from the Social Insurance Institution (in Poland), in recent years, diseases of the musculoskeletal system and connective tissue disorders are the third cause of absenteeism at work of the insured persons (ZUS - Departament Statystyki i Prognoz Aktualnych 2014). It is obvious that many factors that are associated with professional work can effect the emergence of musculoskeletal disorders. These may include physical factors such as carrying out manual transport, during which employees rarely work with the standards. It can also be a forced body posture while performing work, repetitive movements, but also mechanical vibrations or noise (Arezes and Serranheira, 2017; Malińska, Bugajska 2016). The professional group that is exposed to this type of discomfort are also academic teachers. Their work is associated with a high mental and physical load (sitting work, usually at the computer). In the Polish literature on the subject, the assessment of occupational risk as an academic teacher indicates areas of occupational hazards, which are primarily - stress related to interpersonal relationships, the burden of speech associated with teaching, or gastrointestinal ailments associated with poor work organization (Jasiak, Królak 2017; Mohan et al., 2015). Definitely less often, there are symptoms associated with the musculoskeletal system, which can directly affect the effectiveness of the academic teacher's work. However, it seems that in worldwide literature, the topic related to musculoskeletal disorders more often is taken into account. According to them, the aforementioned ailments are the most common health problems of teachers, including academic ones. At the same time, scientists point out that these ailments in the work of an academic teacher are a very neglected topic (Erick, Smith 2015). The academic teacher's work is not only didactic classes with students. It is also the hours of work devoted to preparation for classes or scientific work, which is often done at home, at a time that should be allocated to leisure and private life. The lack of balance between professional work and private life of academic teachers is a fairly common phenomenon. It is sometimes the cause of many disorders, also musculoskeletal disorders resulting from too much exposure to the factors that are their source (Abraham, Igbudu 2018). Therefore, the aim of the paper is an attempt to assess the prevalence and severity of musculoskeletal pain in academic teachers, taking into account the effectiveness of their work. 


\section{METHODOLOGY OF RESEARCH}

The research using a questionnaire has been conducted among academic teachers employed in the academic and didactic position, from January 2019 to April 2019. At that time, 156 questionnaires have been obtained, of which 136 correctly completed questionnaires were finally selected. The survey was anonymous and voluntary. An attempt to assess musculoskeletal disorders has been carried out using a Nordic Musculoskeletal Questionnaire (NMQ) questionnaire, which contains, among others questions about the occurrence of pain within 9 parts of the musculoskeletal system in the last 12 months.For the purpose of the study, to assess the severity of pain, the questionnaire has been supplemented with the Visual Analogue Scale (VAS) scale. The participants of the study have been asked to determine the intensity of pain by marking on a line (with a length of $100 \mathrm{~mm}$ ) a point that characterizes their subjective feelings. The results of the assessment were expressed on a point scale ranging from 0 to 100 , where 0 inticates "no pain” and 100 indicates „the most intense pain” (Figure 1).

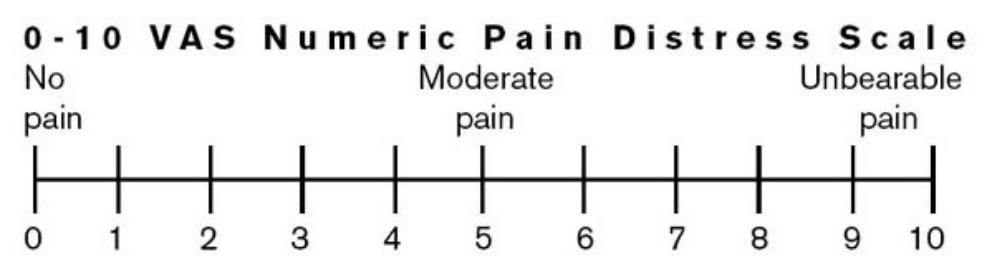

Fig. 1. Linear VAS scale (Visual Analogue Scale)

The parts of the body taken into consideration during the study were: the cervical spine, shoulder joints, elbow joints, wrist joints / hands, thoracic spine, lumbar-sacral spine, hip joints, knee joints and feet (Fig.2).

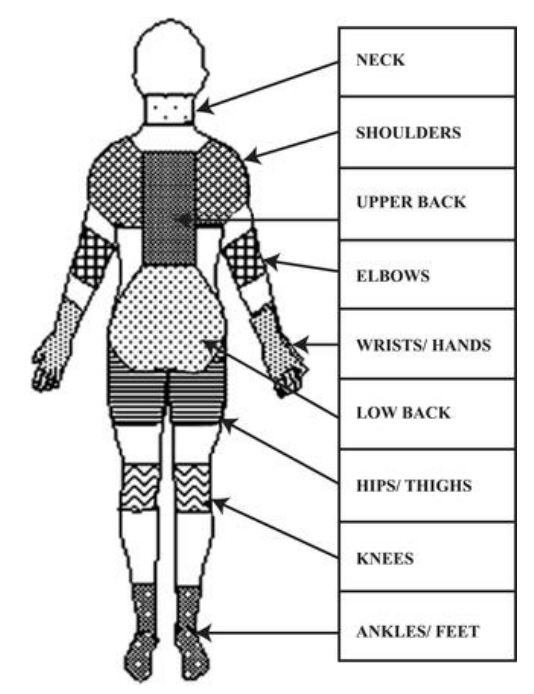

Fig. 2. Body parts considered for pain assessment over the last 12 months

The questionnaire also included questions about the working conditions of academic teachers and the questions of the so-called general, which concerned, inter alia, age, 
work seniority in the occupied position, as well as anthropometric data such as height and weight.

\section{RESULTS AND DISCUSSION}

In the study, 96 women and 40 men employed in universities participated have take a part. The average age of respondent is 39,9. And the number of employees over 50 yars old is about $13,24 \%$ (table 1 ). The average length of service as an academic teacher (work experience in the position of academic teacher) is 14,87 .

Table 1

Age, work experience and BMI (Body Mass Index) in the study group ( $\mathrm{N}, \%)$

\begin{tabular}{|c|c|c|c|}
\hline Variable & Category & $\mathbf{N}$ & $\%$ \\
\hline \multirow[t]{3}{*}{ Age structure } & 25-35 years old & 30 & 22,06 \\
\hline & $36-50$ years old & 88 & 64,70 \\
\hline & $>50$ years old & 18 & 13,24 \\
\hline \multirow{6}{*}{$\begin{array}{l}\text { Work experience in } \\
\text { the occupied position }\end{array}$} & $<1$ year & 2 & 1,47 \\
\hline & $1-5$ years & 8 & 5,88 \\
\hline & $6-10$ years & 20 & 14,71 \\
\hline & $11-15$ years & 50 & 36,76 \\
\hline & $16-20$ years & 38 & 27,94 \\
\hline & $>20$ years & 18 & 13,24 \\
\hline \multirow{6}{*}{$\begin{array}{l}\text { Total work } \\
\text { experience }\end{array}$} & $<1$ year & 2 & 1,47 \\
\hline & $1-5$ years & 8 & 5,88 \\
\hline & $6-10$ years & 20 & 14,71 \\
\hline & $11-15$ years & 50 & 36,76 \\
\hline & $16-20$ years & 38 & 27,94 \\
\hline & $>20$ years & 18 & 13,24 \\
\hline \multirow{6}{*}{$\begin{array}{l}\text { BMI (Body Mass } \\
\text { Index) }\end{array}$} & Underweight & 2 & 1,46 \\
\hline & Overweight & 75 & 56,14 \\
\hline & Correct weight & 40 & 29,30 \\
\hline & $\begin{array}{r}\text { class I obesity } \\
30<\mathrm{BMI}<35\end{array}$ & 16 & 11,70 \\
\hline & $\begin{array}{r}\text { class II obesity } \\
35<\mathrm{BMI}<40\end{array}$ & 2 & 1,46 \\
\hline & $\begin{array}{r}\text { class III obesity } \\
\text { BMI > 40 }\end{array}$ & 1 & 0,74 \\
\hline
\end{tabular}

Source: own study

The research results have showed that over $68 \%$ of the surveyed employees complained about the occurrence of musculoskeletal disorders. The most frequent reports were those between 36 and 50 years old, as well as employees over 50 years old. Employees aged 25-35 (Figure 3) paid less attention to these ailments. 


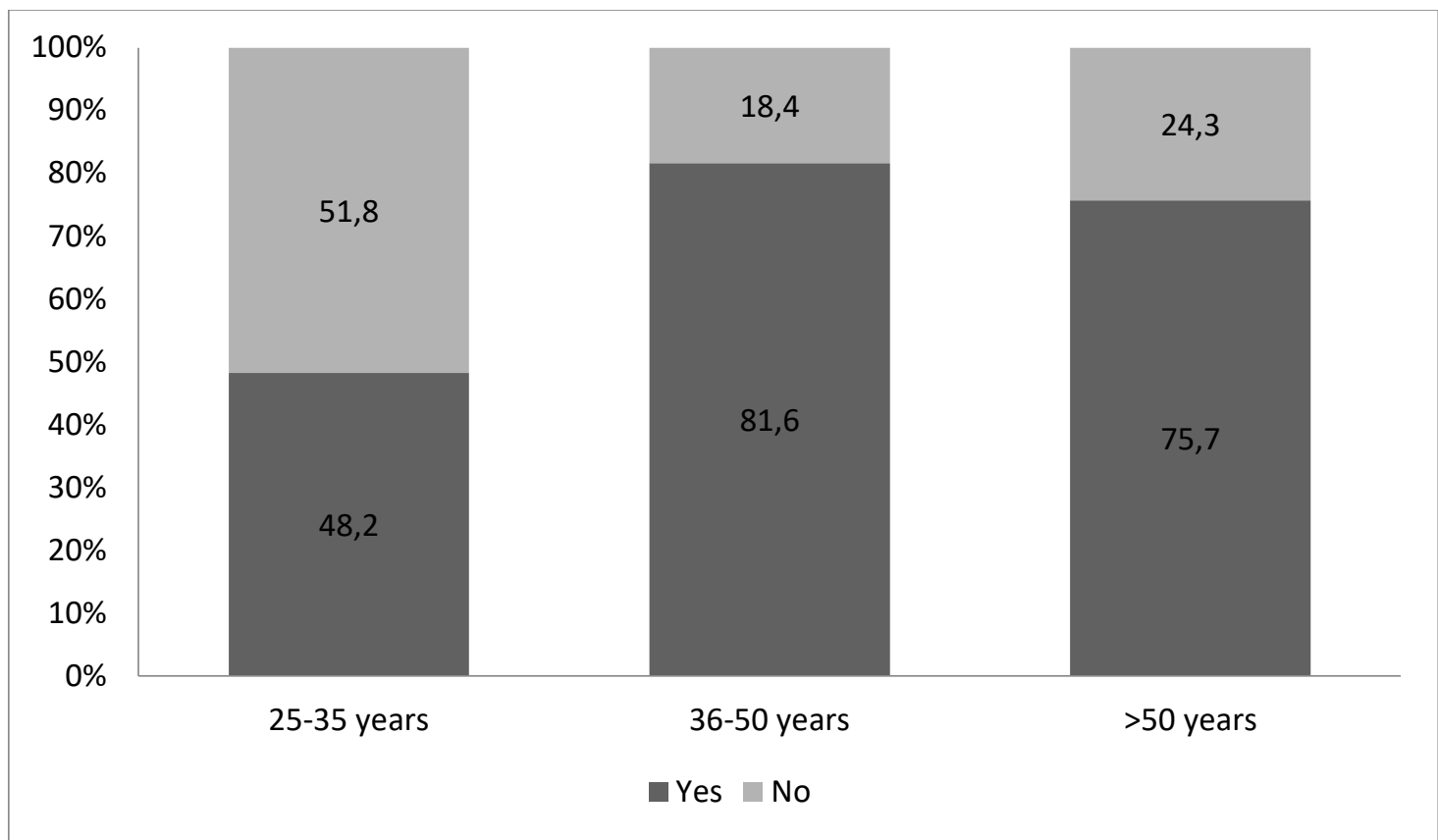

Fig. 3. Occurrence of musculoskeletal disorders depending on the age of the academic teacher

Only 24 respondents indicated the occurrence of complaints in only one part of the motor system. On the other hand, the occurrence of complaints in two parts of the body are reported by 67 persons and in three parts 47 . The disorders in the musculoskeletal system the most frequently indicated by the respondents are:

- back pain in the lumbosacral segment of spine $(25,8 \%)$,

- back pain in the in the thoracic segment of spine $(18,2 \%)$,

- pain in the shoulder joints $(10,3 \%)$,

- pain in the cervical segment of spine $(32,6 \%)$,

- pain in the wrist joints $(5,3 \%)$,

- $\quad$ pain in the elbow joints $(2,4 \%)$,

- $\quad$ pain in the hip joint $(1,2 \%)$,

- pain in the knee joints $(2,4 \%)$,

- footpain $(1,8 \%)$.

Workers aged between 25 and 35 most often indicated the occurrence of pain in the cervical segment of spine (25,8\%). In turn, academic teachers between 36 and 50 years old most often indicated the occurrence of pain in the cervical segment of spine $(32,6 \%)$. Employees at the position of an academic teacher above 50 years old indicated the occurrence back pain in the lumbosacral segment of spine $(36,6 \%)$ (Table 2). 
Table 2

The occurrence of musculoskeletal disorders in individual parts of the body within 12 months based on research conducted among academic teachers

\begin{tabular}{|c|c|c|c|c|c|c|c|c|c|}
\hline Age & $\begin{array}{l}\text { back pain } \\
\text { in the } \\
\text { lumbosacr } \\
\text { al segment } \\
\text { of spine }\end{array}$ & $\begin{array}{c}\text { back } \\
\text { pain in } \\
\text { the in } \\
\text { the } \\
\text { thoraci } \\
c \\
\text { segmen } \\
\text { t of }\end{array}$ & $\begin{array}{l}\text { pain in } \\
\text { the } \\
\text { shoulde } \\
r \text { joints }\end{array}$ & $\begin{array}{l}\text { pain in } \\
\text { the } \\
\text { cervical } \\
\text { segmen } \\
\text { t of } \\
\text { spine }\end{array}$ & $\begin{array}{c}\text { pain } \\
\text { in } \\
\text { the } \\
\text { wrist } \\
\text { joint } \\
s\end{array}$ & $\begin{array}{c}\text { pain } \\
\text { in } \\
\text { the } \\
\text { elbo } \\
w \\
\text { joint } \\
s\end{array}$ & $\begin{array}{c}\text { pai } \\
\mathrm{n} \text { in } \\
\text { the } \\
\text { hip } \\
\text { join } \\
\mathrm{t}\end{array}$ & $\begin{array}{c}\text { pain } \\
\text { in } \\
\text { the } \\
\text { knee } \\
\text { joint } \\
\text { s }\end{array}$ & $\begin{array}{c}\text { footpai } \\
n\end{array}$ \\
\hline $\begin{array}{c}25- \\
35 \\
\text { year } \\
\text { s old }\end{array}$ & 16,5 & 10,5 & 3,8 & 25,8 & 1,8 & 1,2 & 0,3 & 1,2 & 0,4 \\
\hline $\begin{array}{c}36- \\
50 \\
\text { year } \\
\text { s old }\end{array}$ & 32,6 & 21,3 & 10,1 & 38,6 & 2,3 & 1,8 & 1 & 1,8 & 1,2 \\
\hline $\begin{array}{l}>50 \\
\text { year } \\
\text { s old }\end{array}$ & 28,2 & 22,8 & 16,9 & 33,6 & 11,8 & 7,2 & 2,4 & 7,2 & 3,7 \\
\hline All & 25,8 & 18,2 & 10,3 & 32,6 & 5,3 & 2,4 & 1,2 & 2,4 & 1,8 \\
\hline
\end{tabular}

Source: own study

In Table 3 the mean values of pain intensity in individual parts of the body during the last 12 months of work, determined using the VAS scaleis presented. The results refer to research conducted among the group of academic teachers.

Table 3

Evaluation of pain intensity in individual parts of the body over the last 12 months depending on the age of academic teachers

\begin{tabular}{|c|c|c|c|c|c|c|}
\hline & \multirow{2}{*}{\multicolumn{2}{|c|}{$25-35$ yearsold }} & \multirow{2}{*}{\multicolumn{2}{|c|}{$\begin{array}{l}\text { 36-50yearsold } \\
\text { earsold }\end{array}$}} & \multirow{2}{*}{\multicolumn{2}{|c|}{$>$ 50yearsold }} \\
\hline & & & & & & \\
\hline & $\mathbf{N}$ & Meanvalue & $\mathbf{N}$ & Meanvalue & $\mathbf{N}$ & Meanvalue \\
\hline pain in the cervical segment of spine & 11 & 38,8 & 16 & 37,7 & 7 & 50,8 \\
\hline pain in the shoulder joints & 4 & 16,2 & 6 & 17,8 & 1 & 44 \\
\hline $\begin{array}{l}\text { back pain in the thoracic segment of } \\
\text { spine }\end{array}$ & 2 & 35,2 & 22 & 42,8 & 1 & 42 \\
\hline $\begin{array}{l}\text { back pain in the lumbosacral } \\
\text { segment of spine }\end{array}$ & 8 & 22,8 & 34 & 48,9 & 4 & 49,8 \\
\hline wrist joint pain & 1 & 15 & 2 & 8 & 1 & 18 \\
\hline pain in the elbow joints & 1 & 15 & 2 & 7 & 1 & 18 \\
\hline hip joint pain & 1 & 9 & 3 & 4,3 & 1 & 15 \\
\hline pain in the knee joints & 1 & 6 & 2 & 4 & 1 & 10 \\
\hline feet pain & 1 & 6 & 1 & 3 & 1 & 10 \\
\hline
\end{tabular}

Source: own study

The results show that the respondents are most affected by the pain that occurs in the cervical segment $(44,5 \mathrm{~mm})$ and lumbosacral segments of spine $(38,2 \mathrm{~mm})$. 
Academics aged 25-35 indicated the strongest pain to the one from the cervical segment of spine $(38,8 \mathrm{~mm})$.

Employees aged 36-50 as the most severe pain indicated in the thoracic segment of spine $(42,8 \mathrm{~mm})$ and the lumbosacral segment of spine $(48,9 \mathrm{~mm})$. On the other hand, employees over 50 years old as the most severe pain pointed the pain in the cervical $(50,8 \mathrm{~mm})$ and lumbarsacral $(49,8 \mathrm{~mm})$ segments of spine.

Analysis of the impact of occupational factors on the incidence and severity of pain in the musculoskeletal system, which consisted of seniority in total and occupied position, as well as non-professional factors, which consisted of, among others, age, BMI, showed a fairly high correlation in the case of age and seniority of employees $(r$ $=0.784$ ). In addition, it can be noticed that employees over 50 years old more likely complain about the occurrence of pain in the cervical and lumbarsacral segment of spine than in the age of 36-50. Also, the overall work experience significantly, statistically, affected the occurrence of low back (lumbarsacral segment of spine) pain in the spine.

Most of the academic teachers, which have taken the part in the study, admit that they very often exceed their working hours. Over $86 \%$ of respondents claim that apart from working at the university, they also carry out employee tasks at home. Over $90 \%$ of respondents do not apply to computer work standards. Almost every second academic teacher spends more than 8 hours a day at the computer (48\%).

The questionnaire also included questions about the self-assessment of work efficiency. Over $75 \%$ of respondents stated, that they noted the highest efficiency in October-December and March-May (which may result in a long period of rest). In their self-assessment, rest is very important in the regeneration of both physical and mental forces (over 86\%). Mental work, which often takes most of their free time, affects musculoskeletal pain, which in turn indicates the main reason for the decline in efficiency at work (over 78\%). In addition, they indicate that these ailments and overload with mental work have a negative impact on their non-business life (over $80 \%$ ). At the same time, respondents tend to rather intuitively deal with issues of physical activity and activities that minimize musculoskeletal disorders. Most respondents do not know and do not use relaxation techniques during work, which minimize the discomforts resulting largely from working in a sitting position (69\%).

\section{CONCLUSIONS}

Ailments of the musculoskeletal system, especially back pains and muscle pains, are a problem that every fourth employee in European countries suffers from. Reports of the European Agency for Safety and Health at Work for the most frequent complaints of the musculoskeletal system are perceived as pain in the lumbarsacral spine, cervical segment and the thoracic segment of the spine. Academic teachers employed in the scientific and didactic position are particularly exposed to pain in the musculoskeletal system, mainly due to the time of exposure to work in a sitting position, usually at a computer. Most of them do not follow the standards for work with a computer. A photograph of the academic teacher's day clearly indicates that there is not enough time for breaks during which they could use techniques that reduce physical and mental stress, etc. This is mainly due to the poor organization of work. Excessive workload, which often results from the need or obligation of scientific development, means that a large part of the work is also carried out by an academic teacher at home. This, in turn, distorts the balance between professional and non- 
professional life. Lack of adequate rest, regeneration of both physical and mental forces causes a decrease in work efficiency. These are problems that are perceived by the interested people themselves, that is, academic teachers, employed in the didactic and scientific position. However, there are no systemic solutions, in particular related to the safe and ergonomic organization of work and the balance between work and private life. Areas that require effective solutions are primarily time for work breaks, meals at the right time of the day, as well as time for relaxation and family life. The research carried out indicates that there is a great need for a thorough and comprehensive analysis of the subject taken.

\section{REFERENCES}

Abraham N.M., Igbudu J.N., 2018. Managing School Incentive Plans and Work-Life Balance Measures for Teacher Retention in Secondary Schools in Rivers Stale. International Journal of Scientific Research in Education, 11 (5), 847-858.

Arezes, P., Serranheira, F., 2017. New approaches and interventions to prevent Work Related Musculoskeletal Disorders. International Journal of Industrial Ergonomics, 60, 1-2. DOI: 10.1016/j.ergon.2016.10.005

Erick P.N., Smith D.R., 2015. Musculoskeletal disorders in the teaching profession: an emerging workplace hazard with significant repercussions for developing countries. Industrial Health, National Institute of Occupational Safety and Health. 53 (4), 385386.

EU-OSHA, 2017. Zaburzenia układu mięśniowo-szkieletowego, https://osha.europa.eu/pl/themes/musculoskeletal-disorders z dnia 10.01.2019.

Jasiak A., Królak P., 2017. Ocena ryzyka zawodowego starszego wykładowcy na wyższej uczelni technicznej. Organizacja i zarządzanie, 75, 126-140, DOI:10.21008/j.0239-9415.2017.075.10

Klimecka-Tatar, D., Niciejewska, M., 2016a.The OSH management system in the "small-sized" production company.Production Engineering Archives,13/4, 49-52. DOI: 10.30657/pea.2016.13.11

Kogi, K., Sano, Y., Yoshikawa, T., Yoshikawa, S., 2019. The design and use of ergonomic checkpoints for health care work. Advances in Intelligent Systems and Computing, 818, 520-527.

Koradecka D., 2008. Bezpieczeństwo i Higiena Pracy, Wyd. CIOP-PIB, Warszawa.

Malińska M., Bugajska J., 2016. Dolegliwości układu mięśniowo-szkieletowego u pracowników zatrudnionych w budownictwie. Bezpieczeństwo pracy, 8, 8-11.

Mohan, V., Justine, M., Jagannathan, M., Aminudin, S.B., Johari, S.H.B., 2015. Preliminary study of the patterns and physical risk factors of work-related musculoskeletal disorders among academicians in a higher learning institute. Journal of Orthopaedic Science,20(2), 410-417. DOI: 10.1007/s00776-014-0682-4

Niciejewska, M., Klimecka-Tatar, D., 2018. Health problems among employees in small enterprises as a result of improper OHS management. MATEC Web of Conferences 183. 01012. DOI: 10.1051/matecconf/201818301012

Niciejewska, M., Klimecka-Tatar, D., 2016b. Evaluation of Static Load in Dentists' Work by Means of OWAS Method. Czasopismo Techniczne Mechanika, 113, 125130. DOI: $10.4467 / 235373 X C T .16 .131 .5742$

Szabó, G., Németh, E., 2019. Development an Office Ergonomic Risk Checklist: Composite Office Ergonomic Risk Assessment (CERA Office). Advances in Intelligent Systems and Computing, 819, 590-597

ZUS - Departament Statystyki i Prognoz Aktualnych, 2014. Absencja chorobowa w 2014 roku, http://www.zus.pl/files/Absencjachorobowaw2014roku.pdf z dnia 20.02.2019. 